\title{
DNA typing of HLA-A, -C, -B, AND -DRB1 in the children with autism in the Republic of Macedonia
}

\author{
Trajkovski $\mathrm{V}^{1}$, Spiroski $\mathrm{M}^{2}$ \\ Institute of Immunobiology and Human Genetics, Faculty of Medicine, University "Ss. Cyril and Methodius", \\ Skopje, Republic of Macedonia. mspiroski@yahoo.com
}

\begin{abstract}
In the present study, we report the first DNA analysis of HLA class I and class II alleles in Macedonian autistic subjects. We have analyzed the HLA-A, -C, -B, DRB1 genotypes of 35 autistic patients, and 98 healthy unrelated Macedonians (control group). HLA DNA typing of class I genes was performed using a Reverse Line Strip method (RLS), and the Sequencing Based Typing method (SBT) was used for typing of class II genes. In the autistic subjects for HLA-A locus 14 alleles have been identified with 2 being predominant *02 (25.7\%), and *24 (18.6\%). Among the 11 identified HLA-C alleles, 3 were predominant such as *12 (20.0\%), *07 (17.1 $\%)$, and *03 (12.9\%). Among the 18 identified HLA-B alleles, 2 were predominant: *51 (18.6\%), and *18 (11.4 $\%)$. For HLA-DRB1 locus, 10 alleles have been identified with 2 of them predominant such as: ${ }^{*} 11(21.4 \%)$, and ${ }^{*} 01(14.3 \%)$. The allele and haplotype frequencies in the patients group were compared to those of 98 control subjects. Our results showed significantly increased frequencies of HLA-C*03 $\left(\mathrm{OR}=2.74^{\star} ; \chi^{2}=4.68\right.$; $\mathrm{p}=0.03)$, and HLA-DRB1*01 (OR $\left.=3.10 * ; \chi^{2}=6.26 ; \mathrm{p}=0.012\right)$ alleles in autistic patients when compared to the controls. The most frequent haplotype frequencies in autistic sample were A*11-C*12-B*52-DRB1*15 (2.9 $\%), A * 24-C * 03-B * 55-D R B 1 * 16(2.9 \%)$, and $A * 24-C * 03-B * 55-D R B 1 * 16(2.9 \%)$, but they were not statistically significant when compared to the control group. None of our patients carried allele or haplotype, which were protective in our population. Hardy-Weinberg equilibrium in autistic group showed that HLA-A $(p<0.03)$, HLA$C(p<0.04)$, and HLA-DRB1 $(p<0.002)$ loci were in linkage disequilibria. In the control group, we found only for the HLA-DRB1 locus linkage disequilibrium $(p<0.002)$. Our results demonstrated the association of HLAC*03 and HLA-DRB1*01 alleles with Macedonian autistic patients (Tab. 7, Ref. 37). Text in PDF www.elis.sk. Key words: HLA-DNA typing, autism, allele frequencies, haplotype frequencies, Republic of Macedonia.
\end{abstract}

Autism is a chronic developmental disorder characterized by behavioral, communication, and social abnormalities that manifest in the first years of life. Although the etiology of autism is unknown, there is a general agreement that it results from early neurodevelopmental dysfunction (1).

Various research groups have reported numerous-autism associations over the last 20 years. Autism is most likely the result of several different etiologies or a combination of pathological mechanisms. An impressive volume of evidence has accumulated over the past few years suggesting that some cases of autism are associated with immune abnormalities, pathogen-autoimmune processes, and/or HLA. Research continues in several centers in

${ }^{1}$ Institute of Special Education and Rehabilitation, Faculty of Philosophy, University "Ss. Cyril and Methodius", Bull. Krste Misirkov b.b, Skopje, Republic of Macedonia, and 'Institute of Immunobiology and Human Genetics, Faculty of Medicine, University "Ss. Cyril and Methodius", Skopje, Republic of Macedonia

Address for correspondence: $\mathrm{M}$. Spiroski, MD, PhD, Institute of Immunobiology and Human Genetics, Faculty of Medicine, University "Ss. Cyril and Methodius" 1109 Skopje, PO Box 60, Republic of Macedonia. Phone: +389.2.3110556, Fax: +389.2.3110558

Acknowledgement: This research has been supported by grant No 071171/4 (02.07.2001) from the Ministry of Education and Science from Republic of Macedonia. We acknowledge the medical staff of the Department for Mental Health and Department for Rehabilitation of Hear, Speech, and Voice in Skopje for their cooperation in this investigation. the USA and Europe to investigate the link between the immune system and autism. Attempts to identify linkages with autoimmunity, extensive pedigree analysis of autistic subjects and their relatives, and further exploration of immune abnormalities may offer a way of identifying families at increased risk for autism.

Autism is also behaviorally defined, biologically-based developmental disability manifesting in early childhood and affecting boys 4 times frequently than girls (2). Recent investigations suggested that this neurodevelopmental disorder shared many characteristics of established autoimmune disorders including: genetic predisposition (3), immune abnormalities of helper T-cell deficiency and cell-mediated immunity $(4,5)$, antibodies against brain antigens (6), possible microbial triggers-viral infections (7), sex differences (8).

The human immune system can be divided into two arms: the innate (non-specific) and the adaptive (specific), both of which have humoral and cellular components. The innate immune response is constitutively expressed and germ-line encoded and therefore does not adapt to antigen. It is a primitive system that offers the first line of defense and effectively destroys most microorganisms within hours through complement activation. The innate system is also very important in antigen processing and antigen presentation. This is accomplished by antigen binding to HLA-proteins on antigen presenting cells as macrophages and B-lymphocytes. HLA-proteins thus serve as transducers in ac- 
tivating the adaptive immune system by binding to specialized $\mathrm{T}$-cell receptors and B-cell receptors on the surfaces of $\mathrm{T}$ and $\mathrm{B}$ lymphocytes respectively (9).

The major histocompatibility complex (MHC) is a set of genes on the short arm of chromosome number 6 that code for our HLA (human lymphocyte antigens). We all have specific HLA types that determine our ability to accept tissue transplants from others (10). The genes of HLA cover a distance of more than 2 centimorgans of DNA, and contain more than 100 genes. These include genes for the class I molecules, called HLA-A, -C, and -B genes, genes for class II molecules, called HLA-DRB1, -DRB3, -DRB4, -DRB5, HLA-DQB1, and genes for class III. The particular combination of HLA alleles found of the various HLA genes on an individual chromosome is known as an HLA haplotype.

Warren and his colleagues have reported that the allelic products of certain genes of the MHC are associated with autism including the null allele of the $\mathrm{C} 4 \mathrm{~B}$ gene (located in the class III region of the MHC), and the extended haplotype B44-SC30-DR4 (11).

In the present study, we report the first DNA analysis of HLA class I and class II alleles in Macedonian autistic subjects and matched local controls in order to investigate more precisely the genetic association.

\section{Material and methods}

Thirty-five Macedonian patients ( 25 boys and 10 girls) with autism were studied. The mean age was $11 \pm 5.90$ years with minimum 4, and maximum 25 years old. All of these subjects were of Macedonian derivation living in the Republic of Macedonia. DSM-IV and ICD-10 criteria as established by at least two psychiatrists made diagnosis of infantile autism. None of the autistic subjects had an identifiable cause of their disease. Ten milliliters of venous blood was drawn from each donor by the standard venipuncture after parental consent. At the time of blood drawing, none of autistic children were receiving any prescription medication or antipsychotic drug. All measurements were done after the blood samples clotting for storage at $-20^{\circ} \mathrm{C}$. Also included in the study were 98 normal healthy subjects.

Genomic DNA was extracted from whole blood using standard proteinase $\mathrm{K}$ digestion method followed by salting-out extraction and ethanol precipitation (12). HLA DNA typing of class I genes was performed using a Reverse Line Strip method (RLS), and the Sequencing Based Typing method (SBT) was used for typing of class II genes (13-15). Statistical analysis was performed with Arlequin v.2.000 software kindly provided by Excoffier and Slatkin $(16,17)$. In summary, this program calculated HLA-A, $-\mathrm{C}$, -B, and -DRB1 allele frequencies, Hardy-Weinberg equilibrium and the linkage disequilibrium between two alleles at two different loci. The number of autistic subjects and controls from Macedonian population positive for an allele or a haplotype were compared. The Odds Ratio (OR) expressed the strength of the statistical association between the syndrome and genetic markers. The statistical significance was examined by the Chi-square test with Yate's correction.

\section{Results}

In the present study, we investigated the polymorphism of three HLA class I loci: HLA-A, -C, -B, and one HLA class II locus: HLA-DRB1 in 35 autistic patients and 98 unrelated local controls.

The frequencies of HLA-A, -C, -B, and -DRB1 alleles in Macedonian autistic patients compared to the controls are shown in Tables 1, 2, 3 and 4.

HLA-A allele frequencies in persons with autism compared to the control group is shown in Table 1. Fourteen different alleles are found in autistic persons, 4 of them are with allele frequency higher or equal than $10 \%\left(A^{*} 02, A^{*} 24, A^{*} 03\right.$ and $\left.A * 11\right)$. Odds Ratio have not found a statistically higher frequency of some of the alleles in HLA-A locus.

Eleven different HLA-C alleles have been found in the autistic group, from which the most frequent were $C^{*} 12(20 \%)$, $C^{*} 07(17.1 \%)$ and $C^{*} 03(12.9 \%)$. Statistical analysis with Chi-

Tab. 1. HLA-A allele frequencies in Macedonian autistic patients and controls.

\begin{tabular}{lccccc}
\hline $\begin{array}{l}\text { HLA-A } \\
\text { allele }\end{array}$ & $\begin{array}{c}\text { Allele } \\
\text { frequency } \\
\mathrm{n}(\%) \\
\text { controls }\end{array}$ & $\begin{array}{c}\text { Allele } \\
\text { frequency } \\
\mathrm{n}(\%) \\
\text { autism }\end{array}$ & $\begin{array}{c}\text { Odds } \\
\text { ratio } \\
\text { OR }\end{array}$ & $\chi^{2}$ & p-value \\
\hline $\mathrm{A} * 01$ & $19(9.7)$ & $6(8.6)$ & 0.87 & 0.08 & $\mathrm{NS}$ \\
$\mathrm{A} * 2$ & $74(37.7)$ & $18(25.7)$ & 0.57 & 3.31 & $\mathrm{NS}$ \\
$\mathrm{A} * 03$ & $23(11.7)$ & $9(12.9)$ & 1.11 & 0.06 & $\mathrm{NS}$ \\
$\mathrm{A} * 11$ & $12(6.1)$ & $7(10.0)$ & 1.70 & 1.17 & $\mathrm{NS}$ \\
$\mathrm{A} * 23$ & $2(1.0)$ & $1(1.4)$ & 1.41 & 0.15 & $\mathrm{NS}$ \\
$\mathrm{A} * 24$ & $22(11.2)$ & $13(18.6)$ & 1.80 & 1.82 & $\mathrm{NS}$ \\
$\mathrm{A} * 25$ & $3(1.5)$ & $2(2.9)$ & 1.89 & 0.49 & $\mathrm{NS}$ \\
$\mathrm{A} * 26$ & $10(5.1)$ & $2(2.9)$ & 0.55 & 0.19 & $\mathrm{NS}$ \\
$\mathrm{A} * 29$ & $5(2.5)$ & $1(1.4)$ & 0.55 & 0.01 & $\mathrm{NS}$ \\
$\mathrm{A} * 30$ & $2(1.0)$ & $1(1.4)$ & 1.41 & 0.15 & $\mathrm{NS}$ \\
$\mathrm{A} * 31$ & $1(0.5)$ & $1(1.4)$ & 2.83 & 0.00 & $\mathrm{NS}$ \\
$\mathrm{A} * 32$ & $12(6.1)$ & $2(2.9)$ & 0.45 & 0.55 & $\mathrm{NS}$ \\
$\mathrm{A} * 33$ & $1(0.5)$ & $2(2.9)$ & 5.74 & 0.88 & $\mathrm{NS}$ \\
$\mathrm{A} * 66$ & $1(0.5)$ & 0 & 0 & 0.29 & $\mathrm{NS}$ \\
$\mathrm{A} * 68$ & $9(4.6)$ & $5(7.1)$ & 1.60 & 0.67 & $\mathrm{NS}$ \\
\hline Total & $196(100.0)$ & $70(100.0)$ & & & \\
\hline \multicolumn{7}{c}{}
\end{tabular}

Tab. 2. HLA-C allele frequencies in Macedonian autistic patients and controls.

\begin{tabular}{lccccc}
\hline $\begin{array}{l}\text { HLA-C } \\
\text { allele }\end{array}$ & $\begin{array}{c}\text { Allele } \\
\text { frequency } \\
\mathrm{n}(\%) \\
\text { controls }\end{array}$ & $\begin{array}{c}\text { Allele } \\
\text { frequency } \\
\mathrm{n}(\%) \\
\text { autism }\end{array}$ & $\begin{array}{c}\text { Odds } \\
\text { ratio } \\
\text { OR }\end{array}$ & $\chi^{2}$ & p-value \\
\hline $\mathrm{C}^{*} 01$ & $9(4.6)$ & $2(2.9)$ & 0.61 & 0.08 & $\mathrm{NS}$ \\
$\mathrm{C}^{*} 02$ & $19(9.7)$ & $6(8.6)$ & 0.87 & 0.08 & $\mathrm{NS}$ \\
$\mathrm{C}^{*} 03$ & $10(5.1)$ & $9(12.9)$ & $2.74^{*}$ & 4.68 & 0.03 \\
$\mathrm{C}^{*} 04$ & $27(13.8)$ & $6(8.6)$ & 0.59 & 1.29 & $\mathrm{NS}$ \\
$\mathrm{C}^{*} 05$ & $8(4.1)$ & 0 & 2.71 & 1.71 & $\mathrm{NS}$ \\
$\mathrm{C}^{*} 06$ & $8(4.1)$ & $6(8.6)$ & 2.20 & 2.09 & $\mathrm{NS}$ \\
$\mathrm{C}^{*} 07$ & $53(27.0)$ & $12(17.1)$ & 0.56 & 2.74 & $\mathrm{NS}$ \\
$\mathrm{C}^{*} 08$ & $1(0.5)$ & $3(4.3)$ & 8.73 & 2.74 & $\mathrm{NS}$ \\
$\mathrm{C}^{*} 12$ & $32(16.3)$ & $14(20.0)$ & 1.28 & 0.49 & $\mathrm{NS}$ \\
$\mathrm{C}^{*} 14$ & $8(4.1)$ & $5(7.1)$ & 1.81 & 1.04 & $\mathrm{NS}$ \\
$\mathrm{C}^{*} 15$ & $15(7.6)$ & $5(7.1)$ & 0.93 & 0.02 & $\mathrm{NS}$ \\
$\mathrm{C}^{*} 16$ & $3(1.5)$ & $2(2.9)$ & 1.89 & 0.04 & $\mathrm{NS}$ \\
$\mathrm{C}^{*} 17$ & $3(1.5)$ & 0 & 0 & 0.15 & $\mathrm{NS}$ \\
\hline Total & $196(100.0)$ & $70(100.0)$ \\
\hline \multicolumn{7}{c}{}
\end{tabular}


Tab. 3. HLA-B allele frequencies in Macedonian autistic patients and controls.

\begin{tabular}{|c|c|c|c|c|c|}
\hline $\begin{array}{l}\text { HLA-B } \\
\text { allele }\end{array}$ & $\begin{array}{c}\text { Allele } \\
\text { frequency } \\
\mathrm{n}(\%) \\
\text { controls }\end{array}$ & $\begin{array}{c}\text { Allele } \\
\text { frequency } \\
\mathrm{n}(\%) \\
\text { autism }\end{array}$ & $\begin{array}{c}\text { Odds } \\
\text { ratio } \\
\text { OR }\end{array}$ & $\chi^{2}$ & $\mathrm{p}$-value \\
\hline$B * 07$ & $12(6.1)$ & $3(4.3)$ & 0.69 & 0.07 & NS \\
\hline$B * 08$ & $14(7.1)$ & $2(2.9)$ & 0.38 & 1.00 & NS \\
\hline$B * 13$ & $5(2.5)$ & $1(1.4)$ & 0.55 & 0.01 & NS \\
\hline$B * 14$ & $1(0.5)$ & $3(4.3)$ & 8.73 & 2.74 & NS \\
\hline$B * 15$ & $5(2.5)$ & $4(5.7)$ & 2.32 & 0.76 & NS \\
\hline $\mathrm{B} * 18$ & 23 (11.7) & $8(11.4)$ & 0.97 & 0.00 & NS \\
\hline$B * 27$ & $6(3.1)$ & $2(2.9)$ & 0.93 & 0.10 & NS \\
\hline$B * 35$ & $26(13.3)$ & $5(7.1)$ & 0.50 & 1.88 & NS \\
\hline$B * 37$ & $1(0.5)$ & $3(4.3)$ & 8.73 & 2.62 & NS \\
\hline$B * 38$ & $9(4.6)$ & $4(5.7)$ & 1.26 & 0.00 & NS \\
\hline$B * 39$ & $8(4.1)$ & $1(1.4)$ & 0.34 & 0.45 & NS \\
\hline$B * 40$ & $11(5.6)$ & $3(4.3)$ & 0.75 & 0.01 & NS \\
\hline$B * 41$ & $3(1.5)$ & 0 & 0 & 0.15 & NS \\
\hline$B * 44$ & $16(8.2)$ & $4(5.7)$ & 0.68 & 0.16 & NS \\
\hline$B * 45$ & $1(0.5)$ & 0 & 0 & 0.29 & NS \\
\hline$B * 49$ & $3(1.5)$ & $1(1.4)$ & 0.93 & 0.26 & NS \\
\hline B*51 & $33(16.8)$ & 13 (18.6) & 1.13 & 0.11 & NS \\
\hline$B * 52$ & $6(3.1)$ & $5(7.1)$ & 2.44 & 2.17 & NS \\
\hline$B * 53$ & $3(1.5)$ & 0 & 0 & 0.15 & NS \\
\hline$B * 55$ & $6(3.1)$ & $6(8.6)$ & 2.97 & 3.64 & NS \\
\hline$B * 56$ & $1(0.5)$ & 0 & 0 & 0.29 & NS \\
\hline$B * 57$ & $1(0.5)$ & $2(2.9)$ & 5.74 & 0.88 & NS \\
\hline$B * 58$ & $1(0.5)$ & 0 & 0 & 0.29 & NS \\
\hline B*78 & $1(0.5)$ & 0 & 0 & 0.29 & NS \\
\hline Total & $196(100.0)$ & $70(100.0)$ & & & \\
\hline
\end{tabular}

Tab. 4. HLA-DRB1 allele frequencies in Macedonian autistic patients and controls.

\begin{tabular}{lccccc}
\hline $\begin{array}{l}\text { HLA-DRB1 } \\
\text { allele }\end{array}$ & $\begin{array}{c}\text { Allele } \\
\text { frequency } \\
\mathrm{n}(\%) \\
\text { controls }\end{array}$ & $\begin{array}{c}\text { Allele } \\
\text { frequency } \\
\mathrm{n}(\%) \\
\text { autism }\end{array}$ & $\begin{array}{c}\text { Odds } \\
\text { ratio } \\
\text { OR }\end{array}$ & $\chi^{2}$ & p-value \\
\hline DRB1*01 & $10(5.1)$ & $10(14.3)$ & $3.10^{*}$ & 6.26 & 0.012 \\
DRB1*03 & $14(7.1)$ & $5(7.1)$ & 1.00 & 0.00 & NS \\
DRB1*04 & $15(7.6)$ & $3(4.3)$ & 0.54 & 0.47 & NS \\
DRB1*07 & $13(6.6)$ & $4(5.7)$ & 0.85 & 0.00 & NS \\
DRB1*08 & $6(3.1)$ & 0 & 0 & 1.02 & NS \\
DRB1*09 & $1(0.5)$ & 0 & 0 & 0.29 & NS \\
DRB1*10 & 0 & $2(2.9)$ & 0 & 2.46 & NS \\
DRB1*11 & $47(24.0)$ & $15(21.4)$ & 0.86 & 0.19 & NS \\
DRB1*12 & $3(1.5)$ & 0 & 0 & 0.15 & NS \\
DRB1*13 & $18(9.2)$ & $8(11.4)$ & 1.28 & 0.29 & NS \\
DRB1*14 & $6(3.1)$ & $5(7.1)$ & 2.44 & 2.17 & NS \\
DRB1*15 & $25(12.7)$ & $9(12.9)$ & 1.01 & 0.00 & NS \\
DRB1*16 & $38(19.4)$ & $9(12.9)$ & 0.61 & 1.51 & NS \\
\hline Total & $196(100.0)$ & $70(100.0)$ & & & \\
\hline
\end{tabular}

square test have shown a significantly higher frequency of $C^{*} 03$ allele, which can be found 2.5 times more in autistic patients than in healthy population $\left(\mathrm{OR}=2.74 ; \chi^{2}=4.68 ; \mathrm{p}=0.03\right)$ (Tab. 2$)$.

Table 3 presented allele frequency of HLA-B alleles, where 18 different alleles could be seen, with the most frequency in autistic sample of B*51 (18.6\%) and B*18 (11.4\%). None of them were predictive nor protective compared to the control group.

Data from class II, specifically alleles from DRB1 locus are shown in Table 4. Ten different alleles have been found in autistic
Tab. 5. Haplotype frequencies in Macedonian autistic patients and controls.

\begin{tabular}{|c|c|c|c|c|}
\hline Haplotype & $\begin{array}{c}\mathrm{HF} \\
\mathrm{n}(\%) \\
\text { controls }\end{array}$ & $\begin{array}{c}\mathrm{HF} \\
\mathrm{n}(\%) \\
\text { autism }\end{array}$ & $\chi^{2}$ & p-value \\
\hline A*11 C*12 B*52 DRB1*15 & 0 & $2(2.9)$ & 2.21 & NS \\
\hline A*24 C*03 B*55 DRB1*16 & 0 & $2(2.9)$ & 2.21 & NS \\
\hline A*11 C*03 B*55 DRB1*14 & 0 & $2(2.9)$ & 2.21 & NS \\
\hline $\mathrm{A} * 01 \mathrm{C} * 07 \mathrm{~B} * 08 \mathrm{DRB} 1 * 03$ & $6(3.1)$ & 0 & 1.18 & NS \\
\hline A*02 C*07 B*18 DRB1*11 & $4(2.0)$ & 0 & 0.49 & NS \\
\hline A*02 C*06 B*13 DRB1*07 & $3(1.5)$ & 0 & 0.19 & NS \\
\hline A*11 C*12 B*52 DRB1*16 & $3(1.5)$ & 0 & 0.19 & NS \\
\hline
\end{tabular}

Tab. 6. Hardy-Weinberg equilibrium in control group and in persons with autism (HLA-A, -C, -B, -DRB1).

\begin{tabular}{lccccc}
\hline Group & Locus & Genotypes & $\begin{array}{c}\text { Observed } \\
\text { heterozigotes }\end{array}$ & $\begin{array}{c}\text { Expected } \\
\text { heterozigotes }\end{array}$ & $\mathrm{p}$ value \\
\hline Control & HLA-A & 98 & 0.81633 & 0.81737 & 0.71 \\
& HLA-C & 98 & 0.81633 & 0.86290 & 0.12 \\
& HLA-B & 98 & 0.86735 & 0.91753 & 0.23 \\
& HLA-DRB1 & 98 & 0.78571 & 0.86593 & $<0.001$ \\
\hline Autism & HLA-A & 35 & 0.82857 & 0.87205 & $<0.024$ \\
& HLA-C & 35 & 0.80000 & 0.89110 & $<0.038$ \\
& HLA-B & 35 & 0.91429 & 0.93002 & 0.122 \\
& HLA-DRB1 & 35 & 0.80000 & 0.88530 & $<0.002$ \\
\hline
\end{tabular}

Tab. 7. Significant linkage disequilibrium in control group and in persons with autism (HLA-A, -C, -B, -DRB1) (p < 0.05).

\begin{tabular}{lccccc}
\hline Group & Locus & HLA-A & HLA-C & HLA-B & HLA-DRB1 \\
\hline Control & HLA-A & $*$ & + & + & + \\
& HLA-C & + & $*$ & + & - \\
& HLA-B & + & + & $*$ & + \\
& HLA-DRB1 & + & - & + & $*$ \\
\hline \multirow{7}{*}{ Autism } & HLA-A & $*$ & - & - & + \\
& HLA-C & - & $*$ & + & + \\
& HLA-B & - & + & $*$ & + \\
& HLA-DRB1 & + & + & + & $*$ \\
\hline
\end{tabular}

patients, with most frequency of DRB1*11 (21.4\%), DRB1*01 (14.3\%), DRB1*15 (12.9\%) and DRB1*16 (12.9\%). Significantly higher frequency of DRB $1 * 01$ allele compared to control subjects have been found $\left(\mathrm{OR}=3.10 * ; \chi^{2}=6.26 ; \mathrm{p}=0.012\right)$.

In the control population of healthy persons from Macedonia, the most common were the following alleles: $A * 02(37.7 \%), A^{*} 24$ (11.2 \%), B*51 (16.8\%), B*35 (13.3\%), C*07 (27.0\%), C*12 (16.3\%), DRB1*11 (24.0\%) and DRB1*16 (19.4\%).

Four-locus haplotypes and their frequencies are shown in the Table 5. The most common in autistic persons are the following three: A*11-C*12-B*52-DRB1*15 (2.9\%), A*24-C*03-B*55DRB1*16 (2.9\%) and A*11-C*03-B*55-DRB1*14 (2.9\%). Statistical analysis has not detected a significant difference between these three haplotypes, although they are not present in control group. The other haplotypes in autistic sample are present in a relative frequency of $1.4 \%$, which was not statistically significant compared to the haplotype's frequency in control group.

From 172 haplotypes in the control group, four of them were the most frequent: $A^{*} 01-C^{*} 07-B^{*} 08-D R B 1 * 03(3.1 \%), A^{*} 02-$ C*07-B*18-DRB1*11 (2.0\%), A*02-C*06-B*13-DRB1*07 (1.5 $\%)$ and $A * 11-C * 12-B * 52-D R B 1 * 16(1.5 \%)$. Odds Ratio has not 
found a statistically significant difference between the two groups, which proved that existing of these haplotypes in healthy controls have not a protective effect (Tab. 6).

By testing the linkage disequilibrium for all pairs of loci, we get the following results: persons with autism have a statistically significant linkage disequilibrium between locus HLA-DRB1 with the other 3 loci HLA-A, B and C, as well as between HLA$\mathrm{C}$ and HLA-B locus. In the control group we found a statistically significant linkage disequilibrium between the following loci: HLA-A with HLA-C, -B and -DRB1, and HLA-B with -C, and DRB1 (Tab. 7).

\section{Discussion}

The strongest evidence for a link between autism and immune system comes from immunogenetic studies. HLA antigens are involved in the qualitative and quantitative aspects of immune system response. If autism is in some cases the result of immune system attack, then particular HLA antigens might be involved as a sufficient or predisposing factor (18).

The immunogenetic profile of the Macedonian population represented by HLA genes is published for HLA-A, -B, -DR, -DQ allele frequencies (19), for HLA-DRB1, DRB3/4/5 and DQB1 polymorphism (20), for HLA-A and HLA-B epidemiology (21), for high-resolution sequence-based method for direct HLA-DRB1 typing (22), for ambiguous allele combinations at the allele group level of HLA-A, -C and -B loci (23), and for HLA-DQB1 typing (24).

Our results showed significantly increased frequencies of HLA-C*03 and HLA-DRB $1 * 01$ alleles in autistic patients when compared to the controls.

HLA-A, -C, -B, and -DRB1 allele frequencies were used for the Hardy-Weinberg equilibrium analysis.

The detection of A*11-C*12-B*52-DRB1*15 (2.9\%), A*24C*03-B*55-DRB1*16 (2.9\%), and A*24-C*03-B*55-DRB1*16, most common haplotypes in autistic persons are not shown as susceptible haplotypes. These haplotypes has not been detected in the healthy Macedonian population, but there is no statistically significant association, probabely because of the small number of investigated persons with autism. The most common alleles in control group were: $\mathrm{A} * 01-\mathrm{C} * 07-\mathrm{B} * 08-\mathrm{DRB} 1 * 03$ (3.1\%), $\mathrm{A} * 02-$ C*07-B*18-DRB1*11 (2.0\%), A*02- C*06-B*13-DRB1*07 (1.5 $\%), A * 11-C * 12-B * 52-D R B 1 * 16(1.5 \%)$, which is different to the other Macedonian antropological study (19). They found increased frequencies of $\mathrm{A}^{*} 02-\mathrm{B} * 51-\mathrm{DRB} 1 * 1601$ (3.2\%), and A*03-B*18DRB1*1601 (2.6\%) (19). None of our patients carried alleles or haplotype, which are protective for autism in our population.

Specific HLA alleles have been associated with a variety of disorders. A few of the best documented associations include insulin depend diabetes mellitus, multiple sclerosis, celiac disease, and Graves disease (1). Similar association studies have suggested that a susceptibility locus for autism is located in the HLA region.

Warren et al $(8,25)$ and Daniels with his colleagues $(26)$ reported that the allelic products of certain genes of the MHC are associated with autism including the null allele of the C4B gene (located in the class III region of the MHC), and the extended haplotype B44-SC30-DR4, which consists of the 44 allele of the HLA-B region, the $\mathrm{S}$ allele of the $\mathrm{BF}$ gene, the 3 allele of $\mathrm{C} 4 \mathrm{~A}$, the 0 or null allele of $\mathrm{C} 4 \mathrm{~B}$ and the DR4 allele. This extended haplotype has appeared in $40 \%$ autistic subjects and their mothers as compared to $2 \%$ of controls. There are roughly a dozen such extended haplotypes identified that occur at a frequency of 0.0043 or higher and some of these have been associated with diseases, such as rheumatoid arthritis, that are suspected to be autoimmune nature. In the other study, they reported that the third hypervariable region (HVR-3) of certain DRB1 alleles have a very strong association with autism. The HVR- 3 of DRB $1 * 0401$ or the shared HVR-3 alleles DRB $1 * 0404$ and DRB1*0101, have been expressed on extended haplotypes in 23 of 50 (46\%) autistic subjects as compared to only 6 of 79 (7.5\%) normal subjects. Another HVR-3 sequence, the DRB1*0701 allele, have been carried on extended haplotypes in $32 \%$ of the autistic subjects as compared to 10.1 $\%$ of the normal subjects (11). Increased levels of HLA-DR $+\mathrm{T}$ cells and an inverse correlation with plasma C4B levels have been reported in autism (27). It is interesting to note that an abnormality of TNF- $\alpha$ (whose gene is also located in the MHC class III region) production has also been observed in autism. MHC class III genes are in linkage disequilibrium with MHC class II genes, and the C4B null allele is known to be part of the extended or ancestral haplotype in MHC class II region (28). Linkage disequilibrium is a phenomenon in which certain combinations of alleles of the various MHC genes are expressed together far more often than would be expected considering the relative distances between their respective genes (29).

Stubbs et al in 1985 reported that HLA antigens were shared between parents in 39 of 52 (75\%) couples with autistic children compared to $22 \%$ of controls (30), a finding that subsequently could not be repeated (18). In theory, genetic similarities of the immune system between mother and father avoid the usual development of maternal blocking antibodies and therefore, immune tolerance of the mother for the fetoplacental unit and the normal maintenance of pregnancy.

Rogers et al. in 1999 have tested a hypothesis about a role for the HLA loci in the genetic susceptibility to autism. They did that by linkage analysis using genetic marker loci in the HLA region on chromosome $6 \mathrm{p}$ in multiplex families with autism. They have examined sharing of alleles identical by descent in 97 affected sib pairs from 90 families. Their results demonstrated no deviation from null expectation of $50 \%$ sharing of alleles in that region. Thus, it was unlikely that loci in that region contribute to the genetic etiology of autism to any significant extent in our families (1).

Our results for the connection between type I and II alleles in persons with autism in the Macedonian population are different from those published in the literature. While Warren et al (11) found the association with alleles DRB1*0401, DRB1*0101 and $\mathrm{DRB} 1 * 0701$, we found the association with DRB1*01 alleles. His team found the association with HLA-B* allel (27), which we couldn't register in the Macedonian sample of children with autism. We detected an increased frequency of the HLA-C*03 allel and association with autism, data we did not succeed to find in literature. These differences could be due to a different genetic structure of 
the Macedonian population or to different association of the HLA alleles with the autism in the Macedonian population. Additional examinations of the HLA alleles in the families with autism are necessary to get more answers about the Macedonian population.

The associations between human lymphocyte antigen (HLA)A2, B44, DRß1*04 (DR4), C4B, and haplotype B44-SC30-DR4 and autism have been reported in western countries but there is a lack of such information in Asian population. Recently the results showed that the pattern of DRB1 allele frequencies was significantly different between patients with autism and the controls $(p=0.047)$ in Han Chinese. After adjusting for sex by haplotype regression, the frequencies of DR4, DR11, and DR14 were significantly different between patients with autism and healthy controls. In addition, patients with autism and DR4, DR11, or DR14 had different performance on intelligence and neuropsychology tests. Despite a relatively small sample size and a case-control association design, the findings suggest HLA-DRB1 gene might be associated with autism in Han Chinese (31).

Several investigations of transmission disequilibrium (TDT) for HLA in families with autism were investigated. Significant transmission disequilibrium for HLA-DR4 was seen (odds ratio, $4.67 ; 95 \%$ confidence interval, $1.34-16.24 ; \mathrm{p}=.008$ ) for transmissions from maternal grandparents to mothers of probands, supporting a role for HLA-DR4 as an autism risk factor acting in mothers during pregnancy. Transmission disequilibrium was not seen for HLA-DR4 transmissions from parents to probands or from mothers to probands. The HLA-DR4 gene may act in mothers of children with autism during pregnancy to contribute to autism in their offspring (32). The transmission disequilibrium test indicated that the ASD probands inherited the DR4 allele more frequently than expected $(p=0.026)$ from the fathers. The TDT also revealed that fewer DR13 alleles than expected were inherited from the mother by ASD probands $(p=0.006)(33)$. The transmission disequilibrium test for the $\mathrm{A} 2$ allele revealed an increased frequency of inheritance for autistic children $(p=0.033)$. There were no significant associations of autism with HLA-B alleles; however, the A2-B44 and A2-B51 haplotypes were two times more frequent in autistic subjects (34).

Case-control and TDT analysis of intrafamilial transmission of SNPs, Msats, and HLA markers surrounding the $\alpha$ and $\beta$ blocks, indicated significant positive associations for MOGc*131 and D6S2239*105 alleles in ASD, and a negative association of MIB *332 allele in healthy siblings. Polymorphism haplotype analysis demonstrated that two haplotypes comprising the TNF238(G)-TNF-308(G)-MIB*332-HLA-B*38-HLA-Cw*12 and the D6S265*218-HLA-A*23-MOGc*131-rs2857766(G) alleles are more frequently transmitted to ASD. MOGc and MIB loci are linked with ASD in Italian patients (35).

An intrafamilial case-control method (affected family-based controls) and transmission disequilibrium test analysis were used to evaluate the association of microsatellite and SNP markers with ASD-affected children. Results indicated positive associations with ASD for D6S265*220 $(\mathrm{p}<0.01)$ and MOGc*131 $(\mathrm{p}<0.05)$ and negative associations for MOGc*117 and MIB*346 alleles $(p<0.01)$ in ASD children. Polymorphism haplotype analysis indicated that D6S265 allele *220 and MOGc allele *131 were significantly more likely to be transmitted together, as a whole haplotype, to ASD children ( $\mathrm{p}<0.05$ ). Conversely, the D6S265*224MOGc*117-rs2857766(G) haplotype was significantly less frequently transmitted to ASD children $(\mathrm{p}<0.01)$. The results present novel gene markers, reinforcing the hypothesis that genetic factors play a pivotal role in the pathogenesis of ASD (36).

Results of HLA typing indicated that mothers and their sons in the geographically defined group had a significantly higher frequency of DR4 than in normal control subjects (odds ratio $=5.54$, $95 \%$ confidence interval $=1.74-18.67$ and odds ratio $=4.20,95 \%$ confidence interval $=1.37-13.27$, respectively). No significant difference in the distribution of HLA alleles was evident between the United States-all region group and control subjects. Findings of this study are consistent with a hypothesis that prenatal maternal-fetal immune interaction can affect fetal brain development in a population residing in a geographically defined region. Such immune interactions may involve HLA and related genes in both genetic and epigenetic mechanisms during pregnancy (37).

\section{Conclusions}

Our first immunogenetic study in autistic persons in Macedonia found the association with two susceptible loci HLA-C*03 HLA-DRB $1 * 01$ which are possible predictors for autism. We have not found predisposing or protective haplotypes for autism in our Macedonian population.

\section{References}

1. Rogers T, Kalaydjieva L, Hallmayer J, Petersen PB, Nicholas P, Pingree C, McMahon WM, Spiker D, Lotspeich L, Kraemer H, McCague P, Dimiceli S, Nouri N, Peachy T, Yang J, Hinds D, Risch N, Myers RM. Exclusion of linkage to the HLA region in ninety multiplex sibships with autism. J Autism Dev Disord 1999; 29 (3): 195-201.

2. Gillberg C, Wing L. Autism: not an extremely rare disorder. Acta Psychiatr Scand 1999; 99 (6): 399-406.

3. Smalley SL, Asarnow RF, Spence MA. Autism and genetics. A decade of research. Arch Gen Psychiatry 1988; 45 (10): 953-961.

4. Stubbs EG, Crawford ML. Depressed lymphocyte responsiveness in autistic children. J Autism Child Schizophr 1977; 7 (1): 49-55.

5. Warren RP, Margaretten NC, Pace NC, Foster A. Immune abnormalities in patients with autism. J Autism Dev Disord 1986; 16 (2): 189-197.

6. Singh VK, Warren RP, Odell JD, Warren WL, Cole P. Antibodies to myelin basic protein in children with autistic behavior. Brain Behav Immun 1993; 7 (1): 97-103.

7. Stubbs EG. Autistic symptoms in a child with congenital cytomegalovirus infection. J Autism Child Schizophr 1978; 8 (1): 37-43.

8. Warren RP, Singh VK, Cole P, Odell JD, Pingree CB, Warren WL, DeWitt CW, McCullough M. Possible association of the extended MHC haplotype B44-SC30-DR4 with autism. Immunogenetics 1992; 36 (4): 203-207.

9. Torres AR, Maciulis A, Odell D. The association of MHC genes with autism. Front Biosci 2001; 6: D936-943. 
10. Zimmerman AW. The immune system in autism. J Dev Learning Disorders 1999; 3 (1): 3-15.

11. Warren RP, Odell JD, Warren WL, Burger RA, Maciulis A, Daniels WW, Torres AR. Strong association of the third hypervariable region of HLA-DR beta 1 with autism. J Neuroimmunol 1996; 67 (2): 97-102.

12. Miller SA, Dykes DD, Polesky HF. A simple salting out procedure for extracting DNA from human nucleated cells. Nucleic Acids Res 1988; 16 (3): 1215.

13. Voorter CE, Rozemuller EH, de Bruyn-Geraets D, van der Zwan AW, Tilanus MG, van den Berg-Loonen EM. Comparison of DRB sequence-based typing using different strategies. Tissue Antigens 1997; 49 (5): 471-476.

14. McGinnis MD, Conrad MP, Bouwens AG, Tilanus MG, Kronick MN. Automated, solid-phase sequencing of DRB region genes using T7 sequencing chemistry and dye-labeled primers. Tissue Antigens 1995; 46 (3 (Pt 1)): 173-179.

15. Saiki RK, Walsh PS, Levenson CH, Erlich HA. Genetic analysis of amplified DNA with immobilized sequence-specific oligonucleotide probes. Proc Natl Acad Sci U S A 1989; 86 (16): 6230-6234.

16. Schneider S, Roessli D, Excoffier L. Arlequin version 2.000: a software for population genetics data analysis. Geneva (Switzerland): Genetics and Biometry Laboratory, University of Geneva; 2000.

17. Excoffier L, Slatkin M. Maximum-likelihood estimation of molecular haplotype frequencies in a diploid population. Mol Biol Evol 1995; 12 (5): 921-927.

18. Todd RD. Pervasive developmental disorders and immunological tolerance. Psychiatr Dev 1986; 4 (2): 147-165.

19. Arnaiz-Villena A, Dimitroski K, Pacho A, Moscoso J, Gómez-Casado E, Silvera-Redondo C, Varela P, Blagoevska M, Zdravkovska V, Martínez-Laso J. HLA genes in Macedonians and the sub-Saharan origin of the Greeks. Tissue Antigens 2001; 57 (2): 118-127.

20. Hristova-Dimceva A, Verduijn W, Schipper RF, Schreuder GM. HLA-DRB and -DQB1 polymorphism in the Macedonian population. Tissue Antigens 2000; 55 (1): 53-56.

21. Kolevski P, Ivanovski N, Hristova-Dimceva A, Penev M, Cakalaroski K, Lekovski L, Popov Z. [Epidemiology of the major histocompatibility complex-human leukocyte antigen in the Madeconian population]. Ann Urol (Paris) 2000; 34 (5): 306-311.

22. Petlichkovski A, Efinska-Mladenovska O, Trajkov D, Arsov T, Strezova A, Spiroski M. High-resolution typing of HLA-DRB1 locus in the Macedonian population. Tissue Antigens 2004; 64 (4): 486-491.

23. Strezova A, Arsov T, Petlichkovski A, Trajkov D, Efinska-Mladenovska O, Spiroski M. Ambiguous allele combinations at group level of HLA-A, -C, and -B genes in Macedonian population using reverse line strip typing method. Prilozi 2008; 29 (1): 77-91.
24. Djulejic E, Senev A, Kirijas M, Hristomanova S, Petlichkovski A, Trajkov D, Spiroski M. Allele Frequency of HLADQB1 Locus in Macedonian Population. Maced J Med Sci 2012; 5 (1): 67-71.

25. Warren RP, Singh VK, Cole P, Odell JD, Pingree CB, Warren WL, White E. Increased frequency of the null allele at the complement $\mathrm{C} 4 \mathrm{~b}$ locus in autism. Clin Exp Immunol 1991; 83 (3): 438-440.

26. Daniels WW, Warren RP, Odell JD, Maciulis A, Burger RA, Warren WL, Torres AR. Increased frequency of the extended or ancestral haplotype B44-SC30-DR4 in autism. Neuropsychobiology 1995; 32 (3): $120-123$.

27. Warren RP, Yonk J, Burger RW, Odell D, Warren WL. DR-positive $\mathrm{T}$ cells in autism: association with decreased plasma levels of the complement C4B protein. Neuropsychobiology 1995; 31 (2): 53-57.

28. Gupta S. Immunological treatments for autism. J Autism Dev Disord 2000; 30 (5): 475-479.

29. Warren RP, Singh VK, Averett RE, Odell JD, Maciulis A, Burger RA, Daniels WW, Warren WL. Immunogenetic studies in autism and related disorders. Mol Chem Neuropathol 1996; 28 (1-3): 77-81.

30. Stubbs EG, Ritvo ER, Mason-Brothers A. Autism and shared parental HLA antigens. J Am Acad Child Psychiatry 1985; 24 (2): 182-185.

31. Chien YL, Wu YY, Chen CH, Gau SS, Huang YS, Chien WH, Hu FC, Chao YL. Association of HLA-DRB1 alleles and neuropsychological function in autism. Psychiatr Genet 2012; 22 (1): 46-49.

32. Johnson WG, Buyske S, Mars AE, Sreenath M, Stenroos ES, Williams TA, Stein R, Lambert GH. HLA-DR4 as a risk allele for autism acting in mothers of probands possibly during pregnancy. Arch Pediatr Adolesc Med 2009; 163 (6): 542-546.

33. Torres AR, Maciulis A, Stubbs EG, Cutler A, Odell D. The transmission disequilibrium test suggests that HLA-DR4 and DR13 are linked to autism spectrum disorder. Hum Immunol 2002; 63 (4): 311-316.

34. Torres AR, Sweeten TL, Cutler A, Bedke BJ, Fillmore M, Stubbs EG, Odell D. The association and linkage of the HLA-A2 class I allele with autism. Hum Immunol 2006; 67 (4-5): 346-351.

35. Guerini FR, Bolognesi E, Chiappedi M, De Silvestri A, Ghezzo A, Zanette M, Rusconi B, Manca S, Sotgiu S, Agliardi C, Clerici M. HLA polymorphisms in Italian children with autism spectrum disorders: results of a family based linkage study. J Neuroimmunol 2011; 230 (1-2): 135-142.

36. Guerini FR, Bolognesi E, Manca S, Sotgiu S, Zanzottera M, Agliardi C, Usai S, Clerici M. Family-based transmission analysis of HLA genetic markers in Sardinian children with autistic spectrum disorders. Hum Immunol 2009; 70 (3): 184-190.

37. Lee LC, Zachary AA, Leffell MS, Newschaffer CJ, Matteson KJ, Tyler JD, Zimmerman AW. HLA-DR4 in families with autism. Pediatr Neurol 2006; 35 (5): 303-307. 